\title{
O Alto Vale do Itajaí (SC) perante a Ocorrência de Inundações: Uma Abordagem Exploratória
}

\author{
Alto Vale do Itajaí (SC) Facing the Occurrence of Floods: An Exploratory Approach
}

\author{
Ana Paula Klaumann ${ }^{a}$ \\ Hoyêdo Nunes Lins ${ }^{b}$
}

\begin{abstract}
Resumo: A histórica convivência do Alto Vale do Itajaí (AVI) com inundações reflete a configuração de sua bacia hidrográfica e o processo de ocupação da área. $\mathrm{O}$ estudo focaliza esse problema inspirado no debate sobre desenvolvimento territorial rural (DTR), em que se destacam os aspectos históricos, econômicos e socioculturais dos territórios, além de iniciativas de índole cooperativa. O trabalho inicia com uma revisão de literatura acerca do DTR e de sua relação com os desastres naturais; aborda o AVI, mormente a frequência de inundações; faz uma aproximação com as perdas na agricultura; e fala das impressões e dos comportamentos diante das dificuldades em instituições locais e propriedades rurais por meio de entrevistas estruturadas. Por meio do trabalho pôde-se concluir que há abertura para ações institucionais relacionadas à promoção do DTR, e que as ações coletivas são de grande relevância no enfrentamento das adversidades causadas pelos desastres naturais.
\end{abstract}

Palavras-chave: Inundações; Alto Vale do Itajaí; Desenvolvimento Territorial Rural. Classificação JEL: A14. 018. R58.

\begin{abstract}
The historical coexistence of the Alto Vale do Itajaí (AVI) with floods reflects the configuration of its watershed and the occupation process of the area. This paper focuses on this problem inspired by the debate on rural territorial development (RTD), which highlights the historical, economic and socio-cultural aspects of the territories, as well as initiatives of a cooperative nature. The study begins with a literature review about the RTD and its relation to natural disasters; explains the AVI, especially the frequency of flooding; approaches to losses in agriculture, impressions and behavior in the face of difficulties in local institutions and rural properties through structured interviews. From this paper, it can be concluded that there is openness to institutional actions related to the promotion of RTD, and that collective actions are relevant in facing the adversities caused by natural disasters.
\end{abstract}

Keywords: Floods; Alto Vale do Itajaí; Rural Territorial Development.

\footnotetext{
${ }^{\text {a }}$ Graduada em Ciências Econômicas pela UFSC, Mestranda do Programa de Pós-Graduação em Economia da UFRGS. E-mail: anaklaumann96@gmail.com.

${ }^{\mathrm{b}}$ Professor Titular da UFSC, lotado no Departamento de Economia e Relações Internacionais. Integra os corpos docentes dos programas de pós-graduação em Economia e em Relações Internacionais dessa Universidade. E-mail: hoyedo.lins@ufsc.com.
} 


\section{Introdução}

O que se denomina Alto Vale do Itajaí (doravante AVI) corresponde, na regionalização do Instituto Brasileiro de Geografia e Estatística (IBGE) para Santa Catarina, às microrregiões de Ituporanga e Rio do Sul, que perfazem a metade desses recortes na Mesorregião do Vale do Itajaí. A primeira microrregião possui sete municípios, e a segunda, 20, em conjunto, quase coincidindo com a superfície da Associação de Municípios do Alto Vale do Itajaí (Amavi). Esta exibe 28 municípios, que totalizam uma área de 7,5 milhões de $\mathrm{km}^{2}$ (Amavi, 2016) e abriga 269,5 mil habitantes, de acordo com o Censo de 2010 (IBGE, 2010). A diferença é que a Amavi inclui o município de Santa Terezinha, emancipado de Itaiópolis em 1991. A Figura 1, destacando essa associação, permite visualizar a posição do AVI.

A área tem forte presença de atributos rurais. Do total da Amavi, 15 municípios isto é, $54 \%$ - apresentavam a razão população rural/população urbana superior a 1 no Censo de 2010. Em alguns casos essa razão era muito elevada, como em Santa Terezinha $(4,79)$, Chapadão do Lageado $(4,38)$, Witmarsum $(3,26)$, Vitor Meireles $(2,60)$ e Vidal Ramos (2,51). A menor razão correspondia a de Rio do Sul, onde está a maior aglomeração urbana do AVI: a população desse município era de 61,2 mil habitantes, pouco menos de $1 / 4$ do total da região. Também é eloquente que, segundo dados de 2014, metade dos municípios tinha no setor primário pelo menos $20 \%$ do Produto Interno Bruto; para a maior parte (10 municípios) o registro ultrapassou $30 \%$, alcançando $52 \%$ em Santa Terezinha e $44 \%$ em Chapadão do Lageado (IBGE, 2017).

\section{Figura 1: Localização da Área Referente ao Alto Vale do Itajaí}

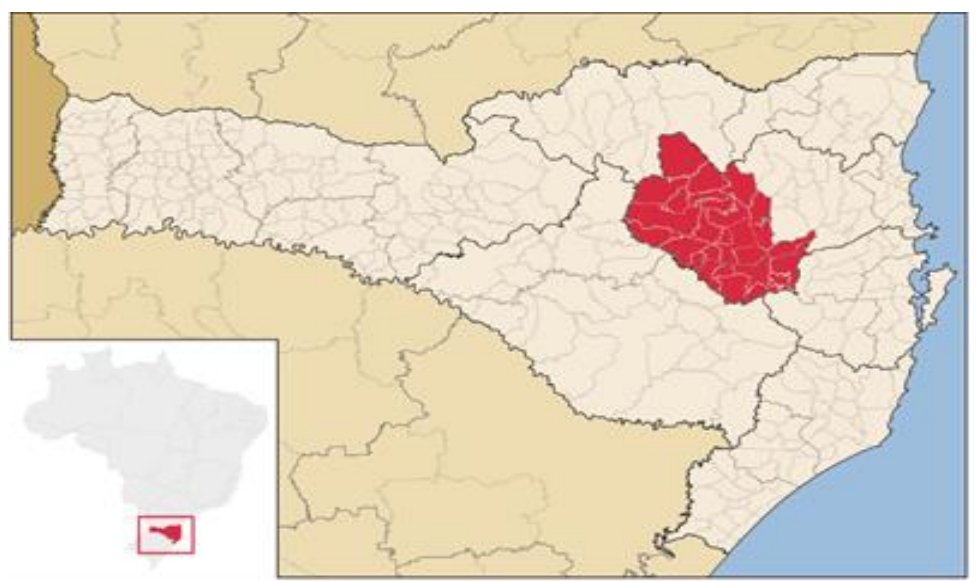

Fonte: https://commons.wikimedia.org/w/index.php?curid=1150925, com adaptação

Outro importante aspecto regional é a histórica recorrência de inundações. Esse fato reflete a configuração de bacia hidrográfica, que apresenta dezenas de rios e ribeirões, tendo como eixo principal o rio Itajaí-Açu, formado com a junção, no território do município de Rio do Sul, dos rios Itajaí do Oeste e Itajaí do Sul. Antes de tocar o litoral, o 
grande curso de água recebe as contribuições do rio ltajaí do Norte, no município de Ibirama; do rio Benedito, no município de Indaial; e do rio Itajaí-Mirim, no município de Itajaí (HENKES, 2002). Note-se que as inundações no Vale do Itajaí nutriram a percepção (não somente local) de que nenhum outro tipo de calamidade tem causado tamanho temor, apreensão e danos em Santa Catarina (SILVA, 1975). Pode-se até falar, de algum modo, na "naturalização" dessas ocorrências: por exemplo, tendo em vista o transbordamento de outubro de 2015 em Rio do Sul, e evocando as proporções de eventos anteriores, Silva (2015, [S.p.]) assinalou que "[...] a inundação faz parte de Rio do Sul, [...] e está praticamente no DNA do riossulense sofrer com alagamentos do Rio Itajaí-Açu. Assistir a água subir, tirar móveis, limpar vitrines, esperar descer, limpar e recomeçar faz [sic] parte de um roteiro já conhecido".

De fato, a história do AVI, como a do Vale do Itajaí de uma forma geral, é uma repetição de inundações. O território foi modelado pelos movimentos de três frentes principais de imigração/colonização: a alemã, que criou os principais núcleos de povoamento, com práticas inicialmente voltadas à subsistência; a italiana, cujos participantes precisaram adquirir suas próprias terras; e a de descendentes de açorianos (MENEZES, 2009). Esses colonizadores necessitaram estabelecer com aquela bacia hidrográfica um "diálogo" pontilhado de ocorrências de inundações, com efeitos que tiveram na própria ocupação, envolvendo desmatamentos e assentamentos, um incontornável fator ou processo determinante.

O "binômio predominância rural - recorrência de inundações", no tocante ao AVI, constitui o foco deste artigo. O objetivo é proporcionar, em abordagem basicamente exploratória, ideias sobre: a) o problema das consequências econômicas das inundações na agricultura; b) o nível de presença e manifestação dos sentidos de coletividade e solidariedade entre atores sociais da área (inclusive institucionais) no trato com as imposições das inundações. O segundo tópico tem relação com questões centrais do debate sobre desenvolvimento territorial rural (daqui em diante DTR), prestigioso internacionalmente e, não parece exagero considerar, também no Brasil, seja na reflexão ou na formulação e execução de políticas.

Daí a escolha desta estrutura de artigo: a próxima parte sistematiza os aspectos do debate sobre DTR; na seguinte, incorpora-se a esse debate o problema dos desastres naturais; depois, fala-se das inundações no AVI e indicam-se perdas recentes em cultivos importantes da região; e, por fim, antes das considerações finais, e com base em pesquisa de campo envolvendo entrevistas (realizadas no segundo semestre de 2017), apontam-se as percepções de atores institucionais e agricultores sobre as inundações e seus danos, realçando o aspecto do envolvimento em ações repletas de sentido comunitário, solidário ou cooperativo. 


\section{Desenvolvimento Territorial Rural (DTR): Alguns Termos do Debate}

Cabe partir, na sistematização contemplada, da própria ideia de território. Esta evoca a agregação, com proximidade geográfica, de práticas e agentes econômicos que interagem entre si e com o meio, tendo como influência os aspectos ou elementos históricos e culturais (BENKO; PECQUEUR, 2001). Assim entendido, o território expressa "delimitação" espacial efetuada por coletividade que se apropria dos recursos locais para se reproduzir (SCHNEIDER; TARTARUGA, 2005). Relações de poder são observadas, mas a literatura sobre DTR costuma sublinhar o aspecto da vivência/convivência. Também se sobressaem os vínculos externos, abrangendo diferentes atores sociais e instituições, pois eles influenciam situações e processos sociais e merecem, portanto, destaque na abordagem do desenvolvimento nessa escala.

Historicamente, os espaços rurais são territórios quase exclusivamente ligados à agropecuária e com baixa densidade populacional, contrastando com o meio urbano e "atrasados" em relação a este. Mas, nas últimas décadas, impôs-se uma mudança de perspectiva na sua abordagem, fruto de transformações que incluíram a diversificação das atividades realizadas (CAMPANHOLA; SILVA, 2000). Ficou até mais difícil diferenciar o rural do urbano, devido, por exemplo, à industrialização do meio rural e ao "transbordamento" do urbano sobre ambientes até então redutos de práticas somente agrícolas. O Brasil não é exceção nessa tendência, pois "Há um conjunto de atividades nãoagrícolas [...] que responde cada vez mais pela nova dinâmica populacional do meio rural brasileiro" (SILVA, 1997, p. 74).

O debate sobre DTR salienta essas mudanças no meio rural, destacando a proeminência de quatro tópicos principais: pobreza; papel e protagonismo político dos atores sociais; território como referência para pensar o desenvolvimento e promovê-lo; e preocupação com a sustentabilidade ambiental (SCHNEIDER, 2004). Para a abordagem deste artigo, o problema do papel e protagonismo político dos atores sociais tem especial importância. Schneider (2010) assinala que, em geral, as elites locais tentam legitimar a sua dominação sociocultural e se perpetuar no poder, criando dificuldades para mudanças nas condições de vida das populações rurais vulneráveis, esfera em que incide a maior pobreza. Contribuiria para isso a fragilidade política, a limitada capacidade e mesmo o desinteresse por mudanças efetivas entre os vários tipos de "[...] atores sociais rurais, sejam eles movimentos sociais ou organizações formais, tais como os sindicatos e as ONGs [...]" (SCHNEIDER, 2010, p.524). Daí a importância de instituições que atuem corretamente na concessão de recursos, reconhecendo direitos e ajudando na emancipação social.

O território é referência básica na reflexão ou promoção do desenvolvimento, por ser palco de importantes relações sociais e políticas. Com carga histórica e cultural, e abrigando instituições cujas funções podem se traduzir em "regulação" social, o território costuma ostentar formas de organização produtiva e divisão do trabalho fortemente influenciadas por seus recursos, em suas várias expressões (CAMPANHOLA; SILVA, 2000). O território, igualmente, destaca-se em relação à problemática da sustentabilidade que cresceu em importância no meio rural porque, entre outros aspectos, as mudanças têm 
sido provocadas pela pressão da concorrência: os produtores tecnologicamente frágeis perdem espaço para os modernizados e são compelidos a um maior uso de agrotóxicos e máquinas pesadas, podendo gerar contaminação das águas, intoxicação humana e desmatamento (GUEDES; TORRES; CAMPOS, 2014; FUNK, BORGES, SALAMONI, 2006).

A agricultura familiar, modalidade na qual a renda auferida depende diretamente da propriedade (geralmente de pequenas dimensões) e em que a família participa amplamente do processo produtivo, desponta no debate sobre DTR. Nessa agricultura, a reprodução econômica e social das famílias depende fortemente da atividade agrícola e da sua capacidade de gerar emprego e renda, sendo forte a presença do autoconsumo, e a identidade cultural é bastante marcada pela influência da "atmosfera" agrícola na definição da, por assim dizer, personalidade familiar, com repercussão no tocante à inserção social. Mas não estão ausentes conflitos referentes à preservação ambiental, pois nem sempre as práticas tradicionais de cultivo mostram elevado sentido de sustentabilidade (CAZELLA; BONNAL; MALUF, 2009).

Sublinhe-se ainda que a esfera comunitária tende a desempenhar no meio rural um importante papel político. As ações coletivas podem não só estimular a execução de políticas públicas, fazendo avançar os projetos por conta das reivindicações, como se mostrarem eficazes na identificação de problemas e na busca de soluções. Com efeito, quem diz ação comunitária diz: “[...] projetos coletivos [que] implicam setores sociais que compartilham objetivos e estratégias, [...] [sendo] as dinâmicas territoriais [...], em parte, uma tradução dos projetos coletivos" (CAZELLA; BONNAL; MALUF, 2009, p. 63). Isso remete à ideia de "sociedade de interconhecimento" em coletividades rurais cujos agentes se conhecem de perto uns aos outros (WANDERLEY, 1999).

\section{Desastres Naturais e o DTR}

Desastres naturais afetam o desenvolvimento rural, necessariamente, e a noção de vulnerabilidade tem importância, nesse caso, referindo-se às condições que influenciam a capacidade das pessoas de se antecipar, resistir e se recuperar (WISNER et al., 2003). O termo evoca "[...] as dimensões da insegurança e a exposição a riscos e perturbações provocados por eventos naturais, [...] possibilitando uma visão mais ampla sobre as condições de vida dos grupos sociais mais pobres [...]" (DUTRA, 2011, p.55). Relacionada diretamente à pobreza, a vulnerabilidade aumenta a importância de instrumentos como crédito e seguro rural (BUAIANAIN et al, 2014), e de políticas públicas (de caráter produtivo ou assistencial), de modo amplo, para enfrentar a baixa capitalização e a restrição tecnológica (JUNQUEIRA; LIMA, 2008).

Esses desastres tendem a agravar os problemas da pobreza rural. Hallegatte et al. (2017) assinalam que as populações mais pobres são as mais afetadas, pois sua exposição aos riscos e suas perdas são proporcionalmente maiores, além de enfrentarem maiores dificuldades na reconstrução de suas vidas. Os problemas avultam, sobretudo, quando ocorre perda de produção, provocando redução na renda, e agravam-se, particularmente, 
quando a infraestrutura ou os equipamentos das propriedades ficam comprometidos, com danos em ferramentas, utensílios, móveis e outros pertences.

Nos ambientes atingidos, reconstituir o espaço e as relações sociais tem sentido de urgência. Para tanto, os indivíduos precisam interagir e atuar coletivamente. De fato, os laços comunitários costumam ajudar na superação de problemas, às vezes envolvendo o associativismo rural, com articulação entre os agricultores. Em situações assim, os esforços são integrados, mirando benefícios conjuntos com a melhoria dos processos produtivos e impulso às atividades, o todo representando o vislumbre da exploração de novas alternativas (SOUZA, 2016). Mas a ação coletiva pode se manifestar sem vínculos com empreendimentos associativos. No debate sobre DTR, aliás, a cooperação representa, muito mais, conduta, prática e espírito, permeando as interações sociais: "Potencialmente, o associativismo, a cooperação, contêm o desenvolvimento local. A associação expressa uma relação dinâmica, uma relação em movimento, em direção a um lugar melhor pela cooperação" (SALOMÃO, 2013, p. 53). A capacidade e a disposição para interagir mostram-se, assim, essenciais, incluindo as relações com instituições, sobretudo as ligadas à vida local: prefeituras, sindicatos rurais e cooperativas, e até mesmo a igreja (apta a canalizar condutas sociais), que podem ajudar a encontrar mecanismos de redução dos impactos dos desastres e catalisar processos de reconstrução.

Eventos como inundações podem afetar a maneira como os grupos sociais atuam no território, devido aos danos e prejuízos que causam (VALENCIO, 2009). As inundações danificam as propriedades e seu entorno, e, por extensão, comprometem as fontes de trabalho e as redes sociais (SIENA, 2009). Assim, a incorporação de outros hábitos e costumes, um processo que diferentes áreas rurais registram há décadas, pode ganhar vigor na esteira dessas catástrofes, surgindo, talvez, novas atividades, embutindo valores, hábitos e técnicas diferentes, mesmo que o espaço rural não resulte completamente descaracterizado ou a essência sociocultural do território se altere drasticamente (CARNEIRO, 1998). Mas como é improvável que todos consigam incorporar atividades acessórias representativas de novas possibilidades, as consequências dos desastres podem impulsionar o êxodo rural. Gervazio, Batista e Cavalcante (2014) destacam, baseados em pesquisa direta, que a migração campo-cidade é explicada não só por busca de emprego, modernização da agricultura e carências na educação e na saúde, entre outros, mas também por desastres naturais como secas e inundações.

Vetor importante dessas catástrofes é a degradação ambiental, como se observa no Brasil com o desmatamento e a ocupação irregular do solo, por exemplo (MAFFRA; MAZZOLA, 2007). A modernização do meio rural, impelida nos anos 1960 por incentivos ao uso de máquinas, adubos, agrotóxicos ou fertilizantes, não parece ter sido acompanhada de atenção equivalente, durante muito tempo, para os efeitos no meio ambiente. "Em vista disso, vários problemas ambientais se intensificaram e outros novos surgiram, oriundos do uso descontrolado dos recursos naturais e também das novas tecnologias que passaram a ser implementadas na agricultura" (OLIVEIRA, 2012, p. 9).

A conservação dos solos e a preservação das encostas ostentam especial importância. De fato, o solo constitui recurso estratégico para a reprodução social, e o uso inadequado 
deste pode provocar o seu esgotamento, razão pela qual deve ser objeto de ações de manutenção. Preservar as encostas e a mata nativa - tanto quanto conservar os solos -, oferece chance de atenuação dos problemas causados pelos desastres, pois a ocupação desordenada, desconsiderando os aspectos ambientais, aumenta os riscos para a população e o próprio meio ambiente. Aliás, a relação entre degradação ambiental e desastres naturais é de determinação mútua: estes afetam diretamente o meio ambiente e representam grandes perdas pela degradação que provocam, mas aquela gera um risco ambiental que pode se traduzir, posteriormente, em desastres naturais.

\section{Alto Vale do Itajaí (AVI): A Recorrência das Inundações}

Última parte do Vale do Itajaí a ser colonizada, o AVI é espaço de confluência de rios (Figura 2), disso resultando o rio Itajaí-Açu. A área atraiu expedições em 1863, 1864 e 1867, quando "[...] foram registrados e mapeados os principais afluentes e formadores do Rio Itajaí, sendo [...] que, na primeira delas [...] [foi] descoberto um novo vale com terras extremamente férteis e passíveis de colonização" (HASS JÚNIOR, 2009, p. 21). Nos primeiros anos chegaram alguns italianos e muitos alemães e caboclos, e a partir de 1913 teve impulso a colonização com pequenas propriedades, trabalhadas por colonos (ou descendentes de) alemães e italianos. Nas primeiras quatro décadas do século XX, trechos das margens dos rios foram ocupados e colonizados nesse processo.

\section{Figura 2: Bacia Hidrográfica do Itajaí-Açu (incluindo todo o Vale do Itajaí)}

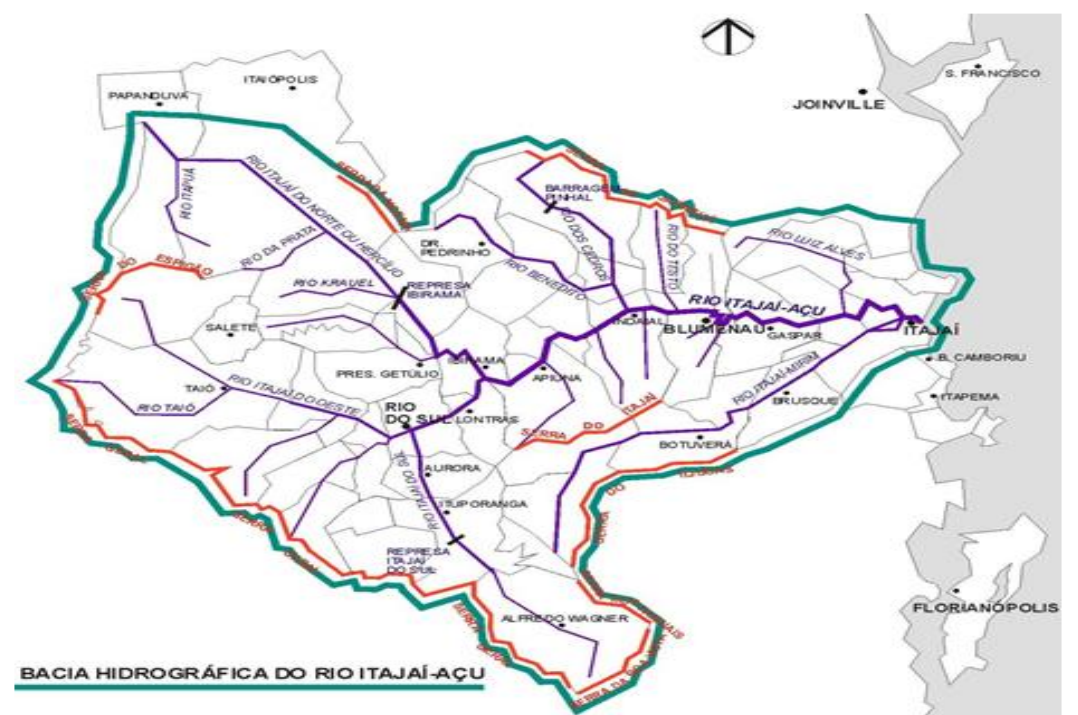

Fonte:http://srv2.lemig.umontreal.ca/donnees/Projet\%20Bresil/cartes/3\%20mapas\%20vale\%20itajai/bacia.jpg 
No início dos anos 1960, os municípios surgidos criaram a Associação dos Municípios do Alto Vale do Itajaí (Amavi), sediada em Rio do Sul, cujas reuniões representam oportunidades para decisões regionais sobre problemas e busca de soluções. Costa (1993, p. 81) assinala que "Analisando-se as atividades desenvolvidas pelos órgãos que compõem a AMAVI, fica evidente a posição da Associação de Municípios como entidade prestadora de serviços [de assistência técnica] e praticamente como extensão das próprias Prefeituras". Já no presente século, em programa do governo estadual alicerçado na descentralização administrativa, criaram-se no AVI quatro Secretarias de Desenvolvimento Regional (SDRs), depois tornadas Agências de Desenvolvimento Regional (ADRs). Rio do Sul deixou de ser o único centro de decisões regionais, compartilhando essa função com os municípios de Ituporanga, Ibirama e Taió, também sedes de SDRs/ADRs.

O AVI amarga inundações desde o início da sua colonização. Os efeitos espelham a ocupação no entorno dos rios, mostrando-se fator agravante o avanço da agricultura sobre a vegetação local, com desmatamentos que intensificam a compactação do solo. Como o AVI está acima dos demais sistemas hídricos, ocorrem rápidos e violentos deflúvios em direção ao litoral, com boa parte das inundações provocando catástrofes de magnitude. Esse é um problema maior da região e, embora lhe perpasse a história, acentua-se com a expansão do desmatamento e da ocupação das margens, motivos de erosão e assoreamento dos leitos dos rios (ESPÍNDOLA; NODARI, 2013).

O Centro de Operações do Sistema de Alerta (Ceops) da Universidade Regional de Blumenau (Furb) compilou dados de 103 anos sobre Rio do Sul (de 1911 a 2014), detectando 46 inundações em 1/3 deles (Ceops/Furb, [S.d.]). Desses eventos, 41,3\% ocorreram no inverno, $30,4 \%$ na primavera, $19,6 \%$ no outono e apenas $8,7 \%$ no verão. $\mathrm{O}$ maior nível atingido pelo rio Itajaí-Açu foi de 13,6 metros em 9/7/1983, sendo que em 9/9/2011 ele atingiu 13,0 metros. O levantamento foi iniciado em 29/5/1911, quando o nível alcançou 12,2 metros em Rio do Sul. Desde então, até 1980, foram registradas 31 inundações nesse município. Segundo Frank (1995), a cada "grande" inundação se iniciava discussão sobre providências, e as "pequenas" mantinham o assunto em pauta. Nesses 103 anos de compilação, estes foram os picos de inundações em Rio do Sul:

- um na década de 1910, em 1911;

- três na de 1920, em 1927 (1) e 1928 (2);

- cinco na de 1930, em 1931 (2), 1933 (1), 1935 (1) e 1937 (1);

- um na de 1940, em 1948;

- nove na de 1950, em 1950 (1), 1953 (1), 1954 (2), 1955 (1) e 1957 (4);

- cinco na de 1960, em 1961 (3), 1966 (1) e 1969 (1);

- dez na de 1970, em 1971 (1), 1972 (1), 1973 (3), 1975 (1), 1977 (1), 1978 (1) e 1979 (2);

- seis na de 1980, em 1980 (1), 1983 (4) e 1984 (1);

- quatro na de 1990, em 1990 (1), 1992 (2) e 1997 (1);

- um na de 2000, em 2001; 
- três na de 2010, até o presente momento, em 2010 (1) e 2011 (2) ${ }^{1}$,

A inundação de 1983, quando o rio atingiu 13,6 metros, foi a maior desse período: 90 municípios foram afetados, dentro e fora do AVI, deixando 197.790 desabrigados e causando 49 mortes (Ceped/UFSC, 2015). Tucci (2003) estimou um prejuízo da ordem de $8 \%$ do PIB de Santa Catarina, pelos efeitos no Vale do Itajaí, cuja recuperação foi prejudicada por outra inundação já no ano seguinte. Ambas as inundações continuam presentes na memória coletiva do Vale do Itajaí e, pela proximidade temporal, são referidas como um só evento. Na segunda década do século XXI, as inundações tornaram-se muito frequentes e provocaram grandes danos. Segundo o Ceops, em 2011, a altura atingida pelo rio foi apenas 60 centímetros inferior à de 1983.

$\mathrm{O}$ estado respondeu com obras, mas as ações têm se revelado paliativas, sem representar uma solução definitiva (na hipótese de que isso seja possível). Foi importante o papel do extinto Departamento Nacional de Obras e Saneamento (DNOS), cujas obras em Santa Catarina foram numerosas, destacando-se as do Vale do Itajaí, onde se buscou reduzir as descargas máximas do rio Itajaí-Açu e seus principais afluentes para retardar o fluxo de grandes volumes de água. O AVI recebeu três barragens: em Taió (Barragem Oeste), Ituporanga (Barragem Sul) e José Boiteux (Barragem Norte), para, conjuntamente, reterem a água nas fases ascendentes das cheias e a esvaziarem nas fases descendentes, o que foi um dos maiores projetos do governo federal na região (FRAGA, 2001).

Em 1986, o DNOS e a Japan International Cooperation Agency (JICA) elaboraram um plano de combate às inundações diante da evidência, nos eventos de 1983 e 1984, de que aquelas barragens não eram suficientes. O Plano Global e Integrado de Defesa Contra Enchentes (Plade) visava proteger a região no longo prazo (50 anos), no médio prazo (25 anos) e, com ações emergenciais, no curso prazo (10 anos), segundo Frank (1994). Mas o Plade não contemplava todos os municípios do AVI e priorizava intervenções exigentes de grandes equipamentos e volumes de concreto. Ora, "No Vale do Itajaí já temos 3 (três) exemplos, 'com as barragens de contenção de cheias', que consumiram muito mais dinheiro do que o necessário e até agora pouco ou nada contribuíram para minimizar o problema [...]" (SCHAFFER; PROCHONOW, 1994, p.59).

Como observou Fraga (2001), esse plano acabou substituído por uma abordagem "mais ampla e politicamente democrática", intitulada Projeto Itajaí, uma "[...] proposta de transformação estrutural do estilo de desenvolvimento [...] do Vale do Itajaí. Incorpora, portanto, uma representação mais clara do problema em termos de um desafio de natureza socioambiental" (MATTEDI, 1994, p. 115). Assinale-se que no ano de 2016 teve início processo licitatório para a construção de duas novas barragens no AVI, em Petrolândia (Edital 0025/2016) e em Mirim Doce (Edital 0024/2016), atualmente (final de 2017) aguardando homologação. A obra de Petrolândia foi orçada pela empresa vencedora em R \$ 23,3 milhões, e a de Mirim Doce, em R\$31,8 milhões (PORTAL DE COMPRAS, 2017).

\footnotetext{
${ }^{1}$ A Defesa Civil de Santa Catarina registrou ainda um evento em setembro de 2013, um em junho de 2014, um em outubro de 2015, e, o mais recente, em junho de 2017.
} 
Cabe ainda observar que, entre 2010 e 2017, o AVI foi objeto de 292 decretos sobre desastres naturais. O Quadro 1 mostra que os municípios que mais decretaram situação de emergência (SE) ou estado de calamidade pública (ECP), nesse período, foram Agronômica e Santa Terezinha. Os anos mais críticos foram 2011 (89 decretos de SE e dez de ECP) e 2013 (41 decretos de SE e três de ECP).

\section{Quadro 1: Decretos de situação de emergência (SE) e de estado de calamidade pública (ECP) por município entre 2010 e 2017}

\begin{tabular}{|c|c|c|c|c|c|c|c|c|c|c|c|c|c|c|c|c|c|}
\hline \multirow{2}{*}{ Município } & \multicolumn{8}{|c|}{ Decretos de situação de emergência } & \multicolumn{8}{|c|}{ Decretos de estado de calamidade pública } & \multirow[t]{2}{*}{ Total } \\
\hline & 10 & 11 & 12 & 13 & 14 & 15 & 16 & 17 & 10 & 11 & 12 & 13 & 14 & 15 & 16 & 17 & \\
\hline Agrolândia & 4 & 4 & 1 & 2 & 2 & 1 & - & 1 & - & - & - & - & - & - & - & - & 15 \\
\hline Agronômica & 2 & 8 & - & 1 & 2 & 2 & - & 1 & - & 1 & - & 1 & - & - & - & - & 18 \\
\hline Atalanta & 2 & 1 & 1 & - & 2 & 2 & - & 1 & - & - & - & - & - & - & - & - & 9 \\
\hline Aurora & - & 4 & - & - & 1 & 2 & - & 1 & - & 1 & - & - & - & - & - & - & 9 \\
\hline B. do Trombudo & - & 6 & - & - & 2 & - & 1 & - & - & - & - & - & - & - & - & - & 9 \\
\hline Ch. do Lageado & 3 & 4 & 3 & 2 & 1 & 1 & - & 1 & - & - & - & - & - & - & - & - & 15 \\
\hline Dona Emma & 2 & 6 & 1 & 2 & 1 & 1 & - & - & - & - & - & - & - & - & - & - & 13 \\
\hline Ibirama & - & 1 & 2 & - & - & 1 & - & 1 & - & - & - & - & - & - & - & - & 5 \\
\hline Imbuia & - & - & 1 & - & - & 1 & - & - & - & - & - & - & - & - & - & - & 2 \\
\hline Ituporanga & - & 3 & 3 & 2 & - & 1 & - & 1 & - & 1 & - & - & - & - & - & - & 11 \\
\hline José Boiteux & 2 & 2 & - & 1 & 1 & 1 & - & - & - & - & - & - & - & - & - & - & 7 \\
\hline Laurentino & 2 & 3 & - & 1 & 4 & 1 & - & 1 & - & 1 & - & 1 & - & - & - & - & 14 \\
\hline Lontras & - & 3 & - & 2 & 1 & 1 & - & 1 & - & 1 & - & - & - & - & - & - & 9 \\
\hline Mirim Doce & 2 & 3 & - & 1 & - & 1 & - & - & - & 1 & - & - & - & - & - & - & 8 \\
\hline Petrolândia & 1 & 2 & 1 & 2 & 2 & 2 & - & 1 & - & - & - & - & - & - & - & - & 11 \\
\hline Pouso Redondo & 1 & 1 & - & - & 1 & 2 & - & - & - & - & - & - & - & - & - & - & 5 \\
\hline Presid. Getúlio & 3 & 4 & - & 2 & 1 & 1 & - & - & - & 1 & - & - & - & - & - & - & 12 \\
\hline Presid. Nereu & 4 & 2 & - & 1 & - & 1 & - & - & - & - & - & - & - & - & - & - & 8 \\
\hline Rio do Campo & 4 & 4 & 2 & 2 & 1 & 1 & 1 & - & - & - & - & - & - & - & - & - & 15 \\
\hline Rio do Oeste & 2 & 2 & - & 2 & 2 & 1 & - & 1 & - & 1 & - & 1 & - & - & - & - & 12 \\
\hline Rio do Sul & - & 5 & - & 2 & 2 & 1 & - & 1 & - & 1 & - & - & - & - & - & - & 12 \\
\hline Salete & 6 & 4 & - & 2 & 1 & 1 & - & - & - & - & - & - & - & - & - & - & 14 \\
\hline Santa Terezinha & 3 & 7 & 2 & 3 & 2 & 2 & - & - & - & - & - & - & - & - & - & - & 19 \\
\hline Taió & 7 & 2 & - & 3 & 1 & 1 & - & 1 & - & 1 & - & - & - & - & - & - & 16 \\
\hline $\begin{array}{c}\text { Trombudo } \\
\text { Central }\end{array}$ & - & 2 & - & 2 & - & 2 & - & - & - & - & - & - & - & - & - & - & 6 \\
\hline Vidal Ramos & - & 3 & 1 & 2 & 1 & 2 & - & 1 & - & - & - & - & - & - & - & - & 10 \\
\hline Vitor Meireles & - & 2 & - & 2 & - & 1 & - & - & - & - & - & - & - & - & - & - & 5 \\
\hline Witmarsum & - & 1 & - & 2 & - & - & - & - & - & - & - & - & - & - & - & - & 3 \\
\hline Total & 50 & 89 & 18 & 41 & 31 & 34 & 2 & 14 & 0 & 10 & 0 & 3 & 0 & 0 & 0 & 0 & 292 \\
\hline
\end{tabular}

Fonte: Elaboração própria com base em SANTA CATARINA ([S.d.])

\section{Uma aproximação ao problema das perdas na agricultura no período recente}

Mensurar os danos causados por eventos climáticos não é tarefa simples, e as perdas estimadas pelas instituições de acompanhamento e análise podem se confirmar ou não. Seja como for, o Centro de Socioeconomia e Planejamento Agrícola da Empresa de Pesquisa 
Agropecuária e Extensão Rural de Santa Catarina (Cepa/Epagri) desempenha importante papel na computação das perdas do setor agropecuário estadual.

Entre setembro e outubro de 2015, o fenômeno El Niño ${ }^{2}$ ganhou intensidade em Santa Catarina e seus efeitos prejudicaram sobremaneira a agropecuária. Isso motivou a elaboração pelo Cepa/Epagri do Relatório Municipal de Perdas na Agropecuária (Cepa/Epagri, 2015a,b), envolvendo escritórios do órgão em todo o estado. A região mais afetada incluiu todo o AVI e também os municípios de Alfredo Wagner, Apiúna e Leoberto Leal, que pertencem às microrregiões de Tabuleiro, Blumenau e Tijucas, respectivamente. As perdas em termos monetários para esse conjunto foram expressivas. As figuras 3 e 4 apresentam esses valores para as cinco culturas mais atingidas nas lavouras temporárias e permanentes.

\section{Figura 3: Principais Perdas Estimadas em Lavouras Temporárias em setembro/outubro de 2015 (Reais a preços correntes) - Conjunto de Municípios Pesquisados e Municípios do AVI}

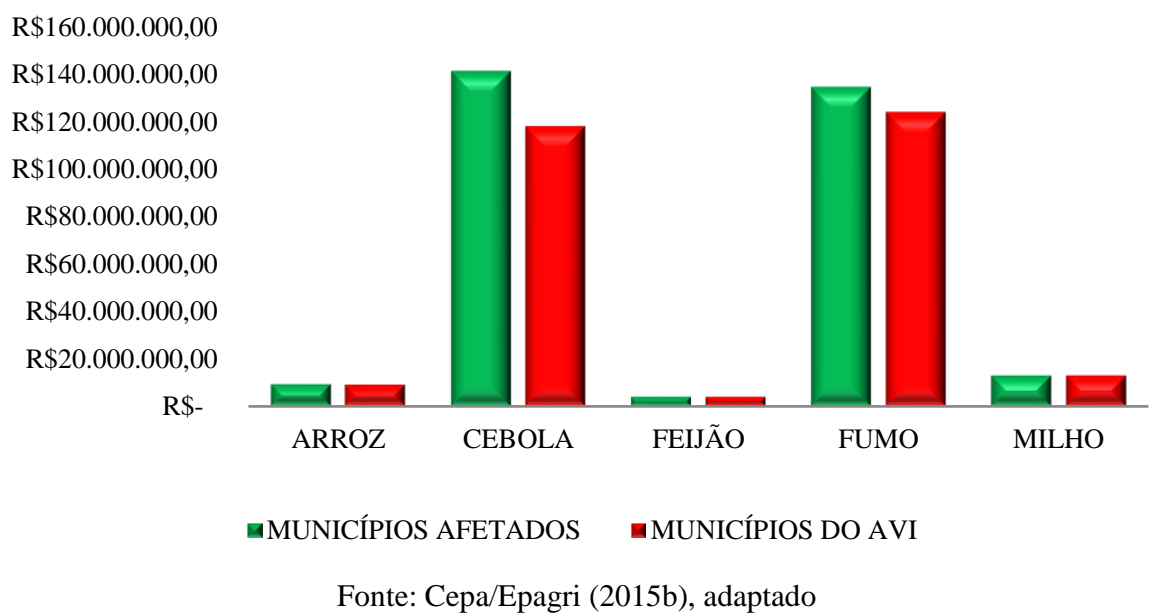

\footnotetext{
${ }^{2}$ Santos, Nascimento e Barros (2011, p.1) dizem que "O fenômeno El Niño consiste no aumento anormal das temperaturas das águas superficiais e sub-superficiais do Oceano Pacífico, [...] [acarretando] modificações no sistema de circulação atmosférica mundial, repercutindo [...] alterações nos elementos climáticos como a temperatura, a precipitação e a umidade e produzindo um comportamento anômalo do clima em diversas áreas do globo terrestre".
} 


\title{
Figura 4: Principais Perdas Estimadas em Lavouras Permanentes em setembro/outubro de 2015 (Reais a preços correntes) - Conjunto de Municípios Pesquisados e Municípios do AVI
}

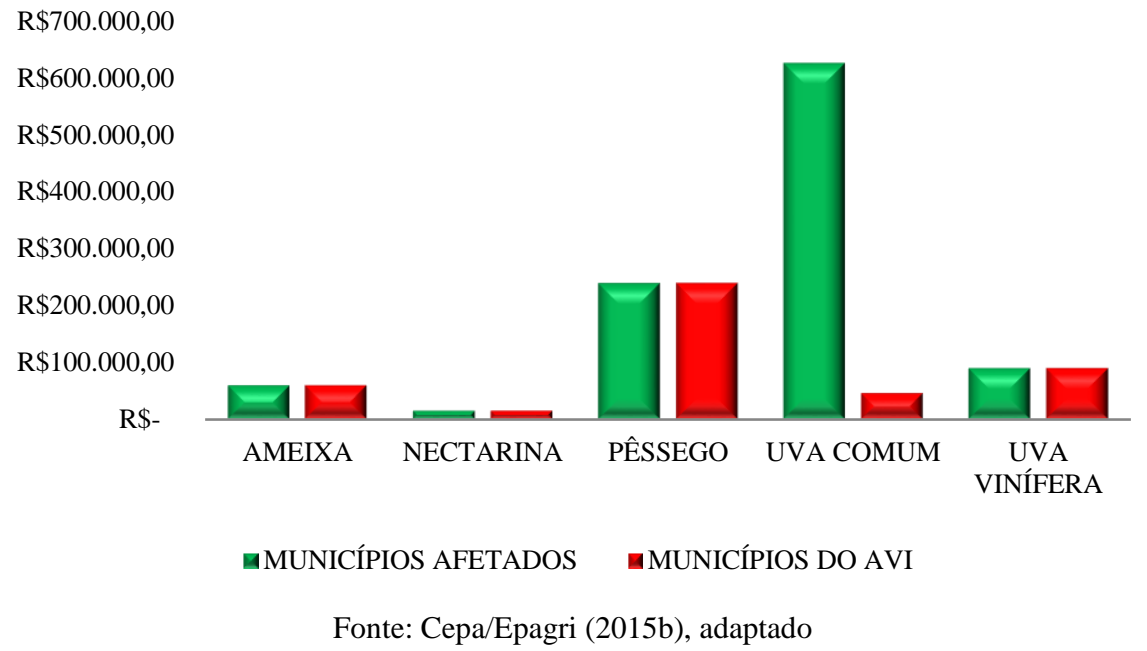

As maiores perdas estimadas referem-se às culturas de cebola e fumo, fortemente representadas na área. O total previsto dessas perdas nos municípios do AVI é de R $\$ 118,0$ milhões e R \$123,8 milhões, respectivamente. Ressalte-se que,

\begin{abstract}
Para a cultura da Cebola, a área atingida com algum tipo de perda chega a 72\% da área plantada, comprometendo cerca de $62 \%$ da produção. Já para a cultura do Fumo, que também sofreu forte impacto, há comprometimento de cerca de $38 \%$ da área estimada de plantio para esta safra, o que representa aproximadamente $27 \%$ de perda em produção. Para essas duas culturas não há possibilidade de recuperação, pois não há tempo nem condição climática para o replantio (Cepa/Epagri, 2015a, p. 1).
\end{abstract}

A Tabela 1 apresenta os municípios do AVI e os cultivos mais prejudicados pelas perdas nas lavouras temporárias durante os referidos eventos de setembro e outubro de 2015. A cebola representou $58 \%$ do valor das perdas, e o município em que tal produto exibe presença particular - Ituporanga - concentrou $46 \%$ do valor total (em cebola e nos demais produtos indicados) perdido no conjunto considerado.

O excesso de chuvas afetou boa parte dos solos do AVI. Com efeito, dos 82.372 ha com lavouras temporárias, 34.435 ha foram prejudicados (41,8 \%). Em Agrolândia, Imbuia e Witmarsum, toda a área plantada foi atingida, e Ituporanga registrou a maior superfície comprometida em termos absolutos. Dos 59 ha com lavouras permanentes, 28,7 ha foram prejudicados (48,6 \%), sendo Petrolândia o município mais castigado (Cepa/Epagri, 2015b). A maior parte das perdas resultou dos efeitos do El Niño. Para os 28 municípios do AVI, as principais causas diretas foram a chuva excessiva (18 municípios), a enxurrada (15) e, em 14 municípios, a inundação ou o granizo (Figura 5). 
Tabela 1: Municípios do AVI Mais Afetados com Fenômenos Naturais no Período de setembro/outubro de 2015: Principais Produtos ( $\mathbf{R}$ mil a preços correntes)

\begin{tabular}{c|c|c|c|c|c}
\hline \hline $\begin{array}{c}\text { Produtos } \\
\text { Municípios }\end{array}$ & Cebola & Feijão & Fumo & Milho & Total \\
\hline Aurora & $16.000,0$ & 114,0 & $4.320,0$ & 460,0 & $20.894,0$ \\
\hline Imbuia & $8.250,0$ & 192,0 & $3.900,0$ & $1.668,0$ & $14.010,0$ \\
\hline Ituporanga & $63.504,0$ & $2.640,0$ & $16.425,0$ & $1.462,0$ & $84.031,0$ \\
\hline Petrolândia & $10.243,2$ & - & $13.860,0$ & $1.218,0$ & $25.321,2$ \\
\hline Santa Terezinha & - & - & $19.250,0$ & 792,0 & $20.042,0$ \\
\hline Vidal Ramos & $7.350,0$ & - & $9.282,0$ & $1.033,2$ & $17.665,2$ \\
\hline Total & $105.347,2$ & $2.946,0$ & $67.037,0$ & $6.633,2$ & $181.963,4$ \\
\hline \hline
\end{tabular}

Fonte: Cepa/Epagri (2015b), adaptado

Figura 5: Principais Causas das Perdas Estimadas na Agropecuária no AVI: $n^{0}$ de Municípios em que se Detectou Cada Causa em setembro/outubro de 2015

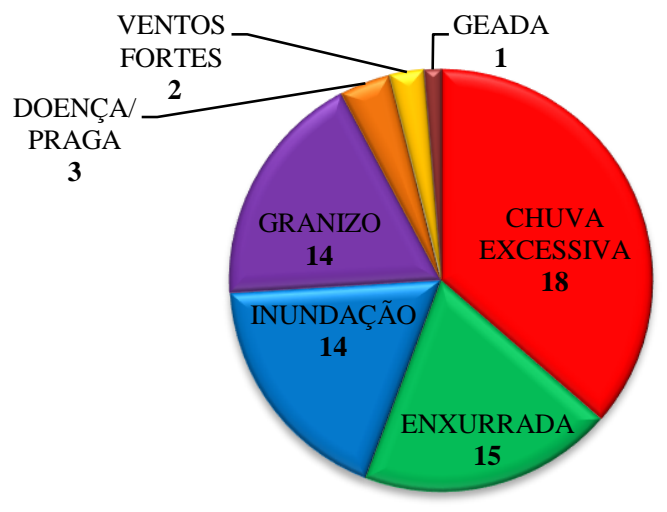

Fonte: Cepa/Epagri (2015b), adaptado

\section{Instituições e Agricultores Diante das Perdas: Um Painel de Observações}

Buscando refinar a percepção sobre as cheias de setembro de 2011 no AVI, entrevistas estruturadas foram realizadas com vários atores locais. A intenção, em cada caso, foi a seguinte:

- Associação dos Municípios do Alto Vale do Itajaí (Amavi): detectar seu papel na prevenção de catástrofes e na promoção da reconstrução. Entrevistou-se o assessor em defesa civil. 
- Associação Empresarial de Rio do Sul (Acirs): levantar impressões sobre os efeitos das inundações na indústria e no comércio, não obstante o foco do estudo no espaço rural. Entrevistou-se o secretário executivo.

- Cooperativa Regional Agropecuária Vale do Itajaí (Cravil): conhecer o entendimento sobre as consequências dos desastres naturais e as recomendações de prevenção aos agricultores. Entrevistou-se o gerente da filial de Ituporanga.

- Empresa de Pesquisa Agropecuária e Extensão Rural de Santa Catarina (Epagri): perceber a visão sobre os problemas causados pelas inundações e as necessidades para enfrentamento. Entrevistou-se o engenheiro agrônomo responsável pela extensão rural da filial de Ituporanga.

- Agricultores: captar a compreensão sobre o significado das inundações em termos de perdas e sobre as ações de controle e atenuação dos efeitos, assim como perceber a existência de espírito comunitário, de ação coletiva e relações cooperativas em face dos eventos. Entrevistaram-se agricultores em quatro propriedades.

\subsection{Impressões nos Âmbitos da Amavi, Acirs, Cravil e Epagri}

O critério de seleção das instituições entrevistadas levou em consideração o conhecimento prévio do grau de proximidade que elas mantêm com a população local, em especial no âmbito rural.

Perguntado sobre a existência de iniciativas para atenuar os efeitos das inundações, o assessor em defesa civil da Amavi afirmou, em entrevista realizada em 4/7/2017, que as ações dessa instituição nesse sentido estão no início e se desenvolvem com a Defesa Civil dos municípios. Essas iniciativas mostram-se cruciais, pois - assinalou respondendo sobre quem sofre com as inundações - "todos são prejudicados, até grandes mercados; claro que as pessoas mais necessitadas, as pessoas com maiores dificuldades financeiras, sofrem muito mais". Indagado sobre o quanto a Amavi interage com outras instituições sobre o problema, um assunto central no debate sobre DTR, o entrevistado admitiu a inexistência de tais vínculos: "Ainda não [há]. Num primeiro momento, o que estamos buscando são capacitações, conversar com os municípios; é claro que depois disso aí a gente vai buscar essas parcerias".

As interações salientadas na entrevista envolvem a Defesa Civil - com respeito à abertura e fechamento das comportas das barragens e dos canais extravasores - e esferas extralocais, situadas em Florianópolis. Tal fato não foi considerado um problema pelo entrevistado

Cheguei na região em 2013 e já participei da enchente desse ano; eu soube que, antes, quem tomava as decisões era o Deinfra ${ }^{3}$, e que depois o poder de abrir e fechar barragem passou para o estado, e, agora, para a Secretaria do Estado de Defesa Civil. Acho que melhorou muito, porque tem grandes profissionais no estado. Tem meteorologista, hidrólogos, engenheiros.

\footnotetext{
${ }^{3}$ Departamento Estadual de Infraestrutura.
} 
O assessor da Amavi também destacou o caráter estratégico da prevenção para enfrentar o problema das inundações. Essa medida não prescinde, na sua opinião, de cooperação envolvendo instituições (públicas e privadas) e setores diversos, uma posição que, sublinhe-se, embute grande realce para um aspecto básico do debate sobre DTR: o esforço conjunto, de perfil colaborativo, em escala territorial.

O secretário executivo da Acirs assim se manifestou, em entrevista realizada em 4/7/2017, sobre as consequências das inundações para a indústria e o comércio:

Desde 2011 a Acirs contribui com a elaboração de questionário para levantar os prejuízos na parte empresarial. Na última enchente, em torno de mil empresas responderam; são empresas [em] que tem algum impacto direto, que a gente diz que 'pegou água na empresa', e outras que não têm impacto direto, mas têm o indireto, pela impossibilidade de os trabalhadores chegarem ou de abrir. Nas últimas cheias esse prejuízo ficou na casa dos 70 milhões, estimados.

Dizer perdas significa dizer que "se perdeu mercadoria, se perdeu estoque, máquinas e equipamentos e, além disso, se perdeu faturamento, [pelos] vários dias com as empresas fechadas. A perda de faturamento talvez seja, no meio empresarial, o maior problema".

Diante de dificuldades dessa magnitude, iniciativas na forma de projetos condizentes e parcerias institucionais parecem decorrências lógicas. Entretanto, ouviu-se na Acirs que "Nós não temos ações específicas. Na parte de infraestrutura, o que podemos fazer é cobrar do setor público para que os projetos estruturantes de prevenção e mitigação de desastres aconteçam". A atuação da Acirs mostra-se, assim, modesta:

No que a gente se envolve [é] participando dos pedidos para prorrogação do prazo de pagamento de tributos e de protestos de títulos. Também tentamos encontrar junto aos bancos condições de financiamento para as empresas; numa situação como essa última [inundação], que foi de emergência, é mais difícil. Fizemos contato com o Badesc ${ }^{4}$, que logo disponibilizou uma linha de crédito.

Os questionários aplicados na Epagri e na Cravil foram muito semelhantes e permitem considerar essas instituições simultaneamente. Perguntado sobre a percepção de perdas pelos agricultores, o engenheiro agrônomo da Epagri responsável pela extensão rural da filial de Ituporanga salientou em entrevista realizada em 9/7/2017 que "Em ano que dá enchente, normalmente o volume de chuvas é maior do que a média e gera prejuízos principalmente pelo apodrecimento na época de colheita e pós-colheita". Mais detalhes foram apresentados pelo gerente da Cravil, em Ituporanga, que assinalou em entrevista efetuada em 20/7/2017 que

Nesse ano [2017] foi fundamental o feijão; nós perdemos de 20 a 25 mil sacos do feijão que ainda estava na lavoura para ser colhido. Também perdemos na outra cultura que estava plantada/semeada, a cebola; tivemos que fazer outro plantio. Outra perda que nós tivemos foi [ligada ao] retardo dessa semeadura, que não foi feita no período mais ideal, e ela pode produzir menos, mais tarde. Outra coisa: o solo, quando chove muito, fica mais compactado, e isso também dificulta; temos que trabalhar, as máquinas agrícolas precisam entrar na lavoura novamente, para soltar o solo, para que as plantas possam se desenvolver melhor. Os solos muitas vezes não estão cobertos com adubação verde, e esses solos nós vamos perder, em

\footnotetext{
${ }^{4}$ Agência de Fomento do Estado de Santa Catarina S.A.
} 
matéria orgânica, e a terra vai indo para os valos, para os rios. Isso é uma das perdas maiores que as enchentes e as chuvas pesadas trazem: o solo.

Sem que isso surpreenda, as próprias atividades dessas instituições são profundamente afetadas pelas inundações. Na Epagri de Ituporanga, informou-se que "A gente tem uma série de experimentos montados em campo, na estação; é como em uma lavoura comum, também tem perdas". Na Cravil, segundo o gerente entrevistado em 2017: “O feijão, nós não compramos, nós íamos comprar muito próximo de 15 mil sacos de feijão, e não entrou nem um quilo nesse período, nós perdemos tudo. Os produtores perderam diretamente o dinheiro em torno de R\$ 3 milhões".

Essas instituições procuram auxiliar os produtores com respeito às consequências das inundações. A Cravil ajuda "em orientação técnica, para eles poderem fazer adubação verde e não perderem nos outros anos. A Cravil é uma cooperativa, nós vamos ajudar; mas financeiramente não há poder para ajudar família por família”. A Epagri, por seu turno, oferece apoio com base na sua estrutura de previsão do tempo, isto é, no Centro de Informações de Recursos Ambientais e de Hidrometeorologia de Santa Catarina (Ciram), que informa, por exemplo, se determinado ano será mais chuvoso, permitindo ao agricultor tomar decisões acertadas. Segundo a entrevista, "se ele sabe que vai ser um ano mais chuvoso, pode programar para, em vez de plantar toda a cebola numa semana ou numa quinzena só, distribuir mais, trabalhar com ciclos diferentes; [ele também] pode fazer uma adubação mais parcelada para ter menos perda de nitrogênio e de potássio".

Sobre a presença de sentido coletivo ou associativo nas relações entre os agricultores em torno das inundações - um tema central, não é demais reafirmar, no debate sobre DTR -, o gerente da Cravil de Ituporanga assinalou uma escassa ocorrência - para não falar em inexistência - de ações assim caracterizadas. "A gente procura fazer várias reuniões técnicas, procurando orientar, mas eu acredito que aqui na região é cada um por si; isso não adianta esconder; acho que eles são meio individualizados". A mesma impressão perpassa o depoimento do engenheiro agrônomo da Epagri:

A gente trabalha, tanto nesse sistema de plantio direto, como nesse de diversificação, de forma associativa. É organizado um grupo, uma associação, um grupo informal para esses agricultores trabalharem. Mas a gente sabe que aqui na nossa região não é fácil trabalhar esse tema. Nosso agricultor, a gente não sabe se pela origem alemã ou outra [razão], não é fácil de trabalhar com associativismo. Tem resistência.

Essa resistência representa problema para avanços. Sendo assim, o interlocutor da Epagri considera representar o procedimento mais adequado para atenuar as perdas dos agricultores:

O que a gente está trabalhando para tentar minimizar [tem a ver com o] plantio direto, a questão da conservação do solo. Isso diminui o problema de uma enchente e recupera a efetividade do solo; diminui o custo de produção do agricultor, que vai ter um sistema mais estável e mais sustentável. Trabalhar essa questão da preservação do solo, é o nosso trabalho aqui na Epagri. E a forma associativa seria o caminho; é o que a gente busca; não é fácil, mas tem que tentar. 


\subsection{Visões no Âmbito da Propriedade Rural}

As quatro propriedades rurais visitadas localizam-se em três municípios do AVI: Ituporanga, Rio do Sul e Agronômica. O critério de seleção para entrevistas, realizadas em 25 e 26 de julho de 2017, considerou o conhecimento prévio de quem tinha sofrido perdas nas inundações de 2011, implicando, segundo as informações obtidas, a totalidade da produção. O Quadro 2 informa sobre traços das propriedades e perdas.

\section{Quadro 2: Propriedades Rurais Estudadas: Algumas Características}

\begin{tabular}{|c|c|c|c|c|c|}
\hline $\begin{array}{l}\text { Proprietários } \\
\text { entrevistados }\end{array}$ & Município & Tamanho & $\begin{array}{c}\text { Pessoas que } \\
\text { trabalham na } \\
\text { propriedade } \\
\end{array}$ & $\begin{array}{c}\text { Safras } \\
\text { afetadas } \\
\text { em } 2011 \\
\end{array}$ & $\begin{array}{c}\text { Valor }(\mathbf{R} \$) \\
\text { aproximado } \\
\text { das perdas } \\
\end{array}$ \\
\hline Casal & Ituporanga & $\begin{array}{c}1,8 \text { hectares } \\
\text { alugados, } \\
\text { com plantio } \\
\text { em } 6 \\
\text { hectares }\end{array}$ & $\begin{array}{l}\text { O casal trabalha } \\
\text { em conjunto com } \\
\text { amigos, trocando } \\
\text { dias de serviço. Ao } \\
\text { todo, oito pessoas } \\
\text { participam do } \\
\text { plantio }\end{array}$ & Cebola & $35.500,00$ \\
\hline Agricultora & Rio do Sul & 3 hectares & $\begin{array}{c}\text { No plantio, a } \\
\text { proprietária, que } \\
\text { paga uma pessoa } \\
\text { para ajudar } \\
\end{array}$ & Milho & $7.700,00$ \\
\hline Agricultor 1 & Agronômica & 9 hectares & $\begin{array}{l}\text { Somente o } \\
\text { entrevistado }\end{array}$ & Arroz & $2.000,00$ \\
\hline Agricultor 2 & Ituporanga & 2,6 hectares & $\begin{array}{c}\mathrm{O} \text { entrevistado e } \\
\text { sua esposa }\end{array}$ & Milho & $\begin{array}{c}\text { De } 4.000,00 \mathrm{a} \\
5.000,00\end{array}$ \\
\hline
\end{tabular}

Fonte: Elaboração própria

Sobre o que representou a inundação de 2011, o casal de proprietários informou:

A gente já estava com a cebola toda plantada. O excesso de chuva começou danificando as terras. Chegou a um ponto em que elas não conseguiram mais suportar aquele volume de água, e começaram a se perder, indo para dentro dos rios. Tivemos que recuperar, fazer aplicação de calcário e tudo o mais, aumentando muito o custo de produção. A cebola estava em fase de desenvolvimento; pegou diversas doenças e boa parte chegou a morrer pelo excesso de água. Isso acabou aumentando o custo e diminuindo a produção e a qualidade do produto. Esse foi o principal impacto na lavoura, e o impacto econômico a gente foi sentindo por um, dois anos, porque tudo que saiu da terra a gente teve que repor; a gente trabalhou com prejuízo e teve que, no ano seguinte, tentar recuperar. Tu acabas trabalhando no limite, com dinheiro de empréstimo.

A agricultora de Rio do Sul disse que "foram muitos [os danos]. Perdemos tudo, tudo! Milho, eu tinha o rancho com 350 sacos para tratar os animais durante o ano, para criar porco, galinha, boi. E foi tudo. Olha, foi duro". O agricultor 1, de Agronômica, falou: "O arroz estava plantado, então precisou comprar semente de novo e plantar de novo", e o agricultor 2, de Ituporanga, assinalou que "O dano foi que carregou o barro embora do terreno, fez um estrago, levou tudo para Santa Tereza [bairro de Aurora]”. 
Sobre o temor da repetição dos desastres, a agricultora de Rio do Sul revelou frequente nervosismo: "Agora a gente tira tudo. Em 2013 a gente tirou tudo; [a água] chegou aqui na frente; em 2015 foi a mesma coisa, e agora, em 2017, deu de novo e entrou na casa". O agricultor 1 afirmou: "Sempre tem [enchente], todo ano praticamente, esses dias já deu de novo".

Como recursos financeiros são necessários, para prevenção ou defesa, perguntou-se sobre o acesso a financiamento. O casal de proprietários de Ituporanga deu este depoimento:

A gente até conseguiu a linha do governo, a determinada taxa de juros, mas o valor do
empréstimo não foi suficiente para cobrir os custos de produção, porque em 2011 se gastou
muito dinheiro em adubação, defensivos agrícolas. Para piorar, a gente ainda sofreu com a
questão da cebola importada; como era pouca cebola no mercado, fizeram a importação da
Espanha e Holanda, principalmente; essa cebola chegou aqui num preço abaixo do mercado,
prejudicando milhares de famílias na nossa região. Esse impacto é sentido até hoje, porque a
cada ano tu vais tendo que cobrir o prejuízo da safra passada, e infelizmente a gente está até
hoje nessa maré, lidando com esse prejuízo que foi causado em 2011 pelas cheias e pela
importação desleal de cebola.

A agricultora de Rio do Sul informou ter necessitado de recursos financeiros: "Fui atrás do Banco do Brasil, mas não consegui nada. Pedi dinheiro emprestado...". Na entrevista do agricultor 1, de Agronômica, a referência foi ao "Pronaf, do Banco do Brasil. Aí, se dá algum problema, tu tens um Proagro, mas ele não cobre tudo. Te ajuda se tem o financiamento, que cobre quase tudo, dependendo da perda: se a enchente atinge tudo ou se atinge a metade...".

Indagou-se sobre a chance de usar a propriedade para alguma outra atividade, tentando a diversificação, e até de deixá-la, em função das catástrofes. A primeira questão quase nem foi considerada, mas sobre a segunda o casal de Ituporanga assinalou:

Esse ano [2017] a gente ainda plantou seis hectares de cebola; se tiver uma safra de razoável a boa, nós vamos tentar mais uma vez; mas se em mais um ano não der preço ou não der sobra de dinheiro, e a gente ficar, mais uma vez, sem nada de lucro ou com prejuízo, aí vamos parar. Não dá mais, daí é a última cartada, é a nossa última tentativa esse ano. Isso é sério, sério mesmo, não tem mais como aguentar.

A agricultora de Rio do Sul indicou ter pensado "em parar, em vender parte da propriedade; mas quem compra? Não tem quem compre. Enquanto eu puder, penso em continuar, porque quando eu não puder mais, meus filhos também não vão querer". $\mathrm{O}$ agricultor 1 disse não ter, até agora, pensado em agregar novos usos à propriedade, inclusive por ser possível que passe a "morar fora daqui". Já o agricultor 2 sequer havia cogitado sair: "Não. Mudar para onde? Para Santa Tereza? Lá já foi água por cima da nossa cabeça uma vez! Não é por encher aqui que eu penso em sair".

Quanto à ocorrência de apoio de instituições voltadas ao meio rural, as opiniões se dividiram. Em duas entrevistas assinalou-se o papel da igreja e da cooperativa. Segundo o casal de proprietários, ambas "sempre estão para ajudar a gente. Mas apoio financeiro eles não têm como prestar, pelo fato de ser muita gente; são milhares de famílias que dependem do mesmo ramo. Não tem como se sustentar, porque o impacto foi para todo mundo que 
plantou cebola naquele ano". A agricultora de Rio do Sul também reconheceu o papel da instituição religiosa, assinalando que "da igreja evangélica a gente ganhou o suficiente para comprar duas camas box; da igreja evangélica da Aurora". Já o agricultor 1 informou que o auxílio institucional é nulo ou quase isso: "Nenhuma instituição [incluindo o governo]. Porque quando dá [problema] aqui, quase todos [os agricultores] perdem, é uma área baixa, tu vês que esse vale aqui onde planta o arroz é uma baixada só, aqui atinge quase tudo". Linha idêntica foi adotada pelo agricultor 2: "Nenhuma instituição". Sobre a atuação do governo, especificamente, o casal de proprietários indicou como problema "a questão burocrática; é dinheiro que vem através de bancos, e em banco tudo tem muito custo, seguros e tudo mais". A agricultora de Rio do Sul, por seu turno, foi enfática: "Do governo, não, nada!"

Deu-se destaque nas entrevistas ao tema da ação coletiva - envolvendo cooperação e demonstrações de solidariedade perpassadas de espírito comunitário -, pelo que representa no debate sobre DTR, como reiterado várias vezes. Subjacente ao interesse, estava a expectativa de que o caráter de "ruralidade" incrustado em grande parte do território do AVI atingido pelas inundações, com suas tradições e possíveis relações e laços de vizinhança e compartilhamento, poderia se expressar em condutas mais aptas a contribuir na atenuação dos problemas. Todavia, confirmando o conteúdo das entrevistas nas instituições, os depoimentos dos agricultores não autorizaram otimismo sobre essa possibilidade. Segundo o casal de proprietários,

Cada família acaba tocando o seu próprio negócio, mas, de modo geral, a gente conversa e agora se está tentando buscar essa questão do associativismo. Estão sendo buscadas melhorias de acompanhamento, até na Anace, que é a nossa Associação Nacional dos Produtores de Cebola. Eles estão começando agora, neste ano, principalmente, uma estratégia para reduzir a questão da importação de cebola. Mas, de modo geral, até ali em 2011 não existia muito o que se fazer, porque a questão é muito generalizada; o prejuízo foi coletivo e muito alto mesmo. Muitos agricultores tiveram que fazer a renegociação dos empréstimos bancários, e foi essa a única atitude que a gente teve.

A agricultora de Rio do Sul falou que "Como eu sempre sou sozinha, não participo [de atividades coletivas], mas a gente tem associação; aí o tratorista vem arrumar a terra...". O agricultor 2 foi mais agudo na sua observação: "Aqui cada um cuida do seu. Na época os caras da prefeitura e da Epagri vieram aqui tirar foto, porque estava feio aqui, mas nunca deu em nada".

Sobre providências no AVI para enfrentar ou prevenir a ocorrência de inundações, é ilustrativo o depoimento da agricultora de Rio do Sul, segundo a qual

\footnotetext{
Antigamente tinha a draga, que limpava o rio, e hoje, como a barragem fica cheia muitas semanas, aquele barranco fica todo mole, cai no rio e no final a gente não tem mais rio, porque ele está cheio de lodo. Eles deveriam começar por ali. Eu moro aqui há 60 anos. Em 1983 deu aquela enchente e em 1984 também, mas choveu semanas e semanas. Hoje qualquer chuva que dá, o rio já está ali em cima. Nós éramos acostumados a sempre plantar milho na parte de baixo do rio; o rio subia meio metro no meio do milho. Em 2011, você olhava aqui, era só água. Hoje, assim que começa a chover, a gente empacota as coisas e ... vamos embora!
} 
Para tentar alguma prevenção os agricultores 1 e 2 exibiram opiniões convergentes sobre a necessidade de manter o rio limpo. Disse o primeiro: "Eu acho que tem que limpar o rio. Ele é muito cheio de entulho; tem lugar que barranco cai, e árvore, tudo, vai para dentro. Tem que limpar, mas ninguém faz, né?". Para o segundo, é essencial "Limpar os rios, que estão cheios de barro e madeira. Acho que é o único jeito".

\subsection{Esboço de Síntese}

As entrevistas que permitiram elaborar esta parte do artigo agregam detalhes à imagem que emerge da seção anterior, que contém uma aproximação ao problema das perdas causadas pelas inundações na agricultura. Lá, o suporte são as informações levantadas pelo Cepa/Epagri a respeito dos eventos de setembro e outubro de 2015, permitindo saber que chuva excessiva, enxurrada, inundação e granizo estiveram por trás de perdas, sobretudo na produção de cebola e de fumo, quanto às lavouras temporárias; e de pêssego e uva, nas permanentes. Aqui, as ocorrências climáticas referem-se a setembro de 2011 e as informações ou impressões registradas foram obtidas pontualmente, mediante entrevistas que, sobretudo no tocante às propriedades rurais, não deixaram de captar aspectos representativos de grande dramaticidade.

Tanto nas instituições como nas propriedades rurais entrevistadas, a visão transmitida é de grandes danos, a realidade específica considerada (setembro de 2011) aparecendo nos relatos como mais um episódio de uma sucessão de adversidades graves, com repercussões generalizadas, porém com consequências devastadoras, notadamente para contingentes pobres do meio rural. As instituições ouvidas procuram atuar, conforme as narrativas, e isso é reconhecido pelos produtores entrevistados, mas em contexto de ausência de procedimentos específicos e estruturantes, de perfil duradouro. As ações limitam-se a providências momentâneas de atenuação das dificuldades, embora se possa considerar que algumas orientações técnicas disponibilizadas, em torno, por exemplo, da adubação verde, tenham perfil de prevenção de danos maiores.

Transparece, sobretudo nesta seção, o caráter bastante rarefeito das ações coletivas diante das enchentes. Esse assunto, recorde-se, diz respeito a um dos dois principais objetivos do estudo, conforme indicado na introdução: captar o nível de presença e de manifestação dos sentidos de coletividade e solidariedade entre atores sociais com referência aos efeitos das inundações. Na indagação sobre o assunto, materializa-se o principal da inspiração representada pelo debate sobre desenvolvimento territorial rural, como tantas vezes se sugeriu no texto. $\mathrm{O}$ escasso sentido de coletividade, com rebatimento nas condutas, foi claramente apontado - e deplorado - no âmbito das instituições, onde se admitiu ser importante lograr avanços a respeito, notadamente, no associativismo. Entre os agricultores, a percepção é de índole semelhante, embora a exposição do espírito individualista tenha atingido particular contundência, como expresso na fala de um agricultor de Ituporanga: "Aqui cada um cuida do seu".

De todo modo, há consenso entre os entrevistados de que é necessário preservar os solos e as encostas, além de manter limpos os rios. Mas também sobre isso transparecem 
os limites impostos pelo baixo nível de espírito coletivo e de ações correspondentes. Como disse o agricultor visitado em Agronômica, todos sabem que "Tem que limpar, mas ninguém faz...".

\section{Considerações Finais}

Em geral, as respostas obtidas ao indagar sobre a realidade observada dependem das perguntas feitas sobre esta. O problema das inundações no AVI foi "interrogado" neste estudo à luz do debate sobre DTR, que chama a atenção, entre outros aspectos, para a importância dos atributos dos territórios (recursos, história, cultura) e para o espírito e as ações, em tal escala, de perfil comunitário, colaborativo e solidário, permeando os comportamentos de grupos sociais e instituições.

Após sistematizar alguma literatura sobre DTR, atribuindo destaque àqueles tópicos, o texto procurou articular, de algum modo, o referido debate com a problemática dos desastres naturais. Na sequência, informou-se sobre perdas no AVI causadas pelas ocorrências de setembro-outubro de 2015, utilizando levantamento disponibilizado no âmbito do Cepa/Epagri. Depois, como resultado de pesquisa direta, mediante entrevistas, detalharam-se registros e impressões em instituições e propriedades rurais sobre perdas e procedimentos relacionados aos eventos climáticos de setembro de 2011.

Nessa investida direta - cuja natureza é eminentemente exploratória - encontra-se impregnado o essencial da inspiração ligada ao debate sobre DTR. Pode-se notar no painel de visões transmitidas pelas entrevistas que há muito por fazer na região a respeito dos problemas das inundações. O terreno está, de fato, aberto às ações institucionais, objetivando formular e executar políticas de promoção do desenvolvimento. Esse tipo de iniciativa, naquela área, ao menos em parte, deve significar atitude voltada ao enfrentamento das adversidades provocadas pelas ocorrências climáticas. O marco, não há equívoco possível em considerar, há de ser o da cooperação, o das ações coletivas crivadas de sentido comunitário e solidário em escala territorial. 


\section{Referências}

AMAVI. Perfil Municipal. [S.d.]. Disponível em:

<https://www.amavi.org.br/perfilmunicipal>. Acesso em: 04 set. 2016 e em 21 ago. 2017.

BENKO, G.; PECQUEUR, B. Os Recursos de Territórios e os Territórios de

Recursos. Geosul, v. 16, n. 32, p. 32-50, 2001.

DOI: https://doi.org/10.1590/S1518-70122006000200007

BUAINAIN, A. M.; SANTANA, C. A. M.; SILVA, F. P.; GARCIA, J. R.; LOYOLA, P. O tripé da política agrícola brasileira: crédito rural, seguro e Pronaf. In: BUAINAIN, A. M.; ALVES, E.; SILVEIRA, J. M.; NAVARRO, Z. (Eds.). O Mundo Rural no Brasil do Século 21: a formação de um novo padrão agrário e agrícola. Brasília: Embrapa, 2014, p. 827-864.

CAMPANHOLA, C.; SILVA, J. G. da. Desenvolvimento local e a democratização dos espaços rurais. Cadernos de Ciência \& Tecnologia, Brasília, v. 17, n. 1, p.11-40, 2000.

CARNEIRO, M. J. Ruralidade: novas identidades em construção. Estudos Sociedade e Agricultura, n. 11, p. 53-75, 1998.

CAZELLA, A.; BONNAL, P.; MALUF, R. Multifuncionalidade da agricultura familiar no Brasil e enfoque da pesquisa. In: CAZELLA, A.; BONNAL, P.; MALUF, R. S. (Orgs.). Agricultura familiar: multifuncionalidade e desenvolvimento territorial no Brasil. Rio de Janeiro: Mauad X, 2009, p. 47-70.

CEOPS/FURB. Picos de enchentes. [S.d.]. Disponível em: <http://ceops.furb.br/index.php/sistema-de-alerta/picos-de-enchentes>. Acesso em: 27 jul. 2017.

CEPA/EPAGRI. Relatório de estimativa de perdas da região do Alto Vale. Florianópolis: Epagri, 2015a.

CEPA/EPAGRI. Relatório de perdas municipais na agricultura. Florianópolis:Epagri, $2015 b$.

CEPED/UFSC. 1983/1984 - Enchentes no Vale de Itajaí em Santa Catarina.

Florianópolis: UFSC, 5 ago. 2015. Disponível em: <http://www.ceped.ufsc.br/19831984enchentes-no-vale-de-itajai-em-santa-catarina/>. Acesso em: 27 jul. 2017.

COSTA, M. M. R. D. Sistema de informação para administração municipal: o caso da AMAVI. 1993. 151 f. Dissertação (Mestrado) - Curso de Pós-Graduação em Administração, Universidade Federal de Santa Catarina, Florianópolis, 1993.

DUTRA, R. de C. Indicadores de vulnerabilidade: no contexto da habitação precária em área de encosta sujeita a deslizamento Florianópolis/SC. 2011. 172 f. Dissertação 
(Mestrado) - Curso de Engenharia Civil, Universidade Federal de Santa Catarina, Florianópolis, 2011.

ESPÍNDOLA, M. A.; NODARI, E. S. Enchentes inesperadas? Vulnerabilidades e políticas públicas em Rio do Sul - SC, Brasil. Esboços, v. 20, n. 30, p.9-34, 19 dez. 2013. DOI: https://doi.org/10.5007/2175-7976.2013v20n30p9

FRAGA, N. C. As enchentes no Vale do Itajaí-Açu/SC: das obras de contenção à indústria da enchente - a problemática ambiental e a relação homem/natureza na busca de soluções. Ra'ega, n. 5, p.125-148, 2001. DOI: http://dx.doi.org/10.5380/raega.v5i1.18320

FRANK, B. O PLADE das obras e o PLADE necessário. Dynamis, v. 2, n. 8, p.11-36, 1994.

FUNK, F.; BORGES, M. A. M.; SALAMONI, G. Pluriatividade: uma estratégia de sustentabilidade na agricultura familiar nas localidades de Capão Seco e Barra Falsa $3^{\circ}$ distrito - Rio Grande - RS. Geografia, v. 15, n. 2, p.51-61, 2006.

DOI: http://dx.doi.org/10.5433/2447-1747.2006v15n2p51

GERVAZIO, W.; BATISTA, E.; CAVALCANTE, L. dos S. O êxodo da juventude camponesa: campo ou cidade? Cadernos de Agroecologia, v. 9, n. 4, p. 1-8, 2014.

GUEDES, A. C.; TORRES, D. A. P.; CAMPOS, S. K. Sustentabilidade e sustentação da produção de alimentos e o papel do Brasil no contexto global. In: BUAINAIN, A. M.; ALVES, E.; SILVEIRA, J. M.; NAVARRO, Z. (Eds.). O Mundo Rural no Brasil do Século 21: a formação de um novo padrão agrário e agrícola. Brasília: Embrapa, 2014, p. 117-146.

HAAS JÚNIOR, A. Horizontes da escrita: historiografia, uma ideia da região e a monumentalização do passado. Alto Vale do Itajaí (1985-2007). 2009. 144 f. Dissertação (Mestrado). Programa de Pós-Graduação em História, Universidade do Estado de Santa Catarina, Florianópolis, 2009.

HALLEGATTE, S.; VOGT-SCHILB, A. C.; BANGALORE, M.; ROZENBERG, J. Unbreakable: building the resilience of the poor in the face of natural disasters. Washington: World Bank Group, 2017. http://dx.doi.org/10.1596/978-1-4648-1003-9

HENKES, S. L. Gestão dos recursos hídricos: acertos e erros na bacia hidrográfica do Rio ltajaí - SC. 2002. 167p. Dissertação (Mestrado). Programa de Pós-Graduação em Engenharias de Produção - Universidade Federal de Santa Catarina, Florianópolis.

IBGE. Cidades, [S.d.]. Disponível em: <https://cidades.ibge.gov.br/>. Acesso em: 2017. IBGE. Sinopse do Censo Demográfico 2010. [S.d.]. Disponível em: <http://www.censo2010.ibge.gov.br/sinopse/index.php?dados=27\&uf=42>. Acesso em: 04 set. 2016. 
JUNQUEIRA, C. P.; LIMA, J. F. de. Políticas públicas para a agricultura familiar no Brasil. Semina: Ciências Sociais e Humanas, v. 29, n. 2, p. 159-176, 2008. http://dx.doi.org/10.5433/1679-0383.2008v29n2p159

MAFFRA, C. Q.T.; MAZZOLA, M. As Razões dos desastres em território brasileiro. In: SANTOS, R. F. dos (Org.). Vulnerabilidade Ambiental: desastres naturais ou fenômenos induzidos? 2. ed. Brasília: Ministério do Meio Ambiente, 2007, p. 9-12.

MATTEDI, M. A. Enchentes em Blumenau: um estudo sobre o comportamento do sistema político no período de 1983-1994. 1994. 149 f. Dissertação (Mestrado) Programa de Pós-Graduação em Sociologia Política, Universidade Federal de Santa Catarina, Florianópolis, 1994.

MENEZES, E. C. de O. Industrialização e meio ambiente no Estado de Santa Catarina: estudo de caso sobre a evolução e os impactos socioambientais do segmento têxtil-vestuarista na microrregião do Alto Vale do Itajaí. 2009. 337 f. Tese (Doutorado) Programa de Pós-Graduação em Sociologia Política, Universidade Federal de Santa Catarina, Florianópolis, 2009.

OLIVEIRA, M. J. G. de S. Meio ambiente e ecodesenvolvimento rural: o impacto do desenvolvimento rural sobre o meio ambiente. In: Simpósio Sobre Reforma Agrária e Questões Rurais: políticas públicas e caminhos para o desenvolvimento, 5, 2012, Araraquara. Anais.... Araraquara: Nupedor, 2012. p. 1-12.

PORTAL DE COMPRAS. Sistema de Acompanhamento de Licitações. [S.d.], Disponível em: <http://www.portaldecompras.sc.gov.br/index.php?option= com_wrapper\&view=wrapper \&Itemid=178>. Acesso em: 2017.

SANTA CATARINA. Decretação de SE e ECP. Florianópolis: Defesa Civil, [S.d.]. Disponível em: < http://www.defesacivil.sc.gov.br/index.php/municipios/ decretacoes.html>, acesso em 2017.

SALOMÃO, M. V. F. Associativismo e desenvolvimento local: o papel das associações comunitárias da Ilha de São Nicolau (Cabo Verde). 2013. 111 f. Dissertação (Mestrado) Curso de Sociologia, Ciências Sociais, Universidade do Minho, Braga, 2013.

SANTOS, N. B. F. dos; NASCIMENTO, D. T. F.; BARROS, J. R. Influência do fenômeno Índice de Oscilação Sul (El Nino e La Nina) na temperatura de superfície do bioma cerrado. In: Simpósio Internacional de Climatologia, 2011, João Pessoa-PB. Anais do IV SIC, 2011.

SCHAFFER, W. B.; PROCHONOW, M. O PLADE e a realidade do Alto Vale. Dynamis, v. 2, n. 8, p.57-60, 1994.

SCHNEIDER, S. A abordagem territorial do desenvolvimento rural e suas articulações externas. Sociologias, v. 6, n. 11, p. 88-125, 2004. 
SCHNEIDER, S. Situando o desenvolvimento rural no Brasil: o contexto e as questões em debate. Revista de Economia Política, v. 30, n. 3, p. 511-531, 2010.

DOI: https://doi.org/10.1590/S0101-31572010000300009

SCHNEIDER, S.; TARTARUGA, I. G. P. Território e abordagem territorial: das referências cognitivas aos aportes aplicados à análise dos processos sociais rurais. Raízes, v. 23, n. 01 e 02, p. 99-116, 2005.

SIENA, M. A vulnerabilidade social diante das tempestades: da vivência dos danos na moradia à condição de desalojados/desabrigados pelo recorte de gênero. In: VALENCIO, Norma; SIENA, Mariana; MARCHEZINI, Victor; GONÇALVES, Juliano Costa. (Orgs.). Sociologia dos Desastres: construção, interfaces e perspectivas no Brasil. São Carlos: Rima Editora, 2009, p. 69-79.

SILVA, Â. Com histórico de enchentes e quarto transbordamento do rio só em outubro, Rio do Sul vive rotina de reconstrução. O Sol Diário. Itajaí. 24 out. 2015.

SILVA, J. F. da. As enchentes no Vale do Itajaí. Blumenau: Casa Dr. Blumenau, 1975. SILVA, José Graziano da. O novo rural brasileiro. Nova Economia, v. 7, n. 1, p. 43-81, 1997.

SOUZA, F. B. de. Associativismo rural: uma análise da associação comunitária Barra da Espingarda em Caicó/RN. 2016. 73 f. Monografia (Bacharelado) - Programa de PósGraduação em Geografia, Universidade Federal do Rio Grande do Norte, Caicó, 2016.

TUCCI, C. E. M. Inundações e drenagem urbana. In: TUCCI, C. E. M.; BERTONI, J. C. (Orgs.). Inundações Urbanas na América do Sul. V. 1. Porto Alegre: Associação Brasileira de Recursos Hídricos, 2003, p. 45-150.

VALENCIO, Norma. Da "área de risco" ao abrigo temporário: uma análise dos conflitos subjacentes a uma territorialidade precária. In: VALENCIO, Norma; SIENA, Marina; MARCHEZINI, Victor; GONÇALVES, Juliano Costa. (Orgs.). Sociologia dos Desastres: construção, interfaces e perspectivas no Brasil. São Carlos: Rima Editora, 2009, p. 34-47.

WANDERLEY, M. de N. B. Raízes históricas do campesinato brasileiro. In: TEDESCO, J. C. (Org.). Agricultura Familiar: realidades e perspectivas. Passo Fundo: EDIUPF, 1999, p. 21-55

WISNER, B.; BLAIKIE, P.; CANNON, T.; DAVIS, I. At Risk: natural hazards, people's vulnerability and disasters. 2. ed. London: Routledge, 2003. 